\title{
Central Nervous System B-Cell Lymphoma in Multiple Sclerosis
}

\section{Multipl Sklerozda Merkez Sinir Sistemi B Hücreli Lenfomast}

\author{
Mark LYONS, Naresh PATEL, Barry BIRCH, Orland BOUCHER \\ Mayo Clinic Arizona, Department of Neurological Surgery, Phoenix/AZ, USA
}

Correspondence address: Mark LYONS / E-mail: lyons.mark2@mayo.edu

\begin{abstract}
The differential diagnosis of multiple sclerosis is extensive and it can be challenging to diagnose initially in the absence of pathognomonic clinical features. Furthermore, these patients can also develop other diseases during their course of treatment, which usually lasts for many years. Some conditions, such as primary central nervous system lymphoma, can mimic clinically some of the symptoms prominent in multiple sclerosis. Early treatment with corticosteroids can also dramatically improve patient symptoms in both conditions. We report a case of a man diagnosed with histologically confirmed relapsing remitting multiple sclerosis who subsequently developed histologically confirmed primary central nervous system lymphoma. The course of his disease and treatment are presented and the current literature reviewed.
\end{abstract}

KEYWORDS: Multiple sclerosis, Primary central nervous system lymphoma, Brain biopsy, Interferon, Magnetic resonance imaging

öz

Multipl sklerozun ayırıcı tanısı geniştir ve patognomonik klinik özellikler yokluğunda başlangıçta tanı konması zor olabilir. Ayrıca bu hastalarda genellikle yıllar süren tedavileri sırasında başka hastalıklar gelişebilir. Primer merkez sinir sistemi lenfoması gibi bazı durumlar multipl sklerozda ön planda olan belirtileri klinik olarak taklit edebilir. Ayrıca kortikosteroidler ile erken tedavi her iki durumda hasta belirtilerinde dramatik bir iyileşme sağlayabilir. Histolojik olarak doğrulanmış tekrarlayan düzelen multipl skleroz tanısı konmuş ve daha sonra histolojik olarak primer merkez sinir sistemi lenfoması gelişen bir erkek vaka sunuyoruz. Bu hastalığın seyri ve tedavisi sunulmuş ve mevcut güncel literatür gözden geçirilmiştir.

ANAHTAR SÖZCÜKLER: Multipl skleroz, Primer merkez sinir sistemi lenfoması, Beyin biyopsisi, İnterferon, Manyetik rezonans görüntüleme

\section{INTRODUCTION}

The association of relapsing remitting multiple sclerosis (RRMS) and the development of primary central nervous system lymphoma (PCNSL) is not clear. Both conditions can initially respond to corticosteroid administration. Patients can be misdiagnosed with a demyelinating disease while actually harboring a neoplastic process. Other patients can potentially develop a neoplastic disease several years following their diagnosis of multiple sclerosis. We report a case of a man with multiple sclerosis who subsequently developed histopathologically-confirmed primary central nervous system lymphoma and discuss the current literature.

\section{CASE REPORT}

A 53-year-old man developed acute diplopia and vertigo which persisted for ten weeks and then resolved. A magnetic resonance (MR) imaging study of the brain demonstrated increased T2-weighted signal abnormality in the right middle cerebral peduncle which did not enhance. No treatment was pursued. One year later, following an emergency appendectomy, the symptoms of diplopia and vertigo recurred. These symptoms persisted over the following two months along with dysarthria, dyscoordination and sphincteric dysfunc- tion. A follow-up MR demonstrated progression of the signal abnormalities on the brain MR. He was diagnosed with possible multiple sclerosis and treated with three days of methyIprednisolone. The treatment resulted in improvement in his symptoms. He was referred to our institution four months later with the presumptive diagnosis of relapsing remitting multiple sclerosis (RRMS).

Six months later, the patient had some gradual neurological deterioration and underwent a five day treatment with methylprednisolone that resulted in some improvement in his symptoms. Unfortunately, he continued to have progressive symptoms. The patient was scheduled to be enrolled in the CombiRx (interferon beta-1a and glatiramer acetate) trial. Subsequent MR imaging demonstrated increased abnormal signal with cystic changes in the right frontal lobe. The imaging features were considered somewhat unusual for RRMS and he underwent a stereotactic brain biopsy (Figure 1). Biopsy confirmed demyelinating disease with CD68 stain demonstrating numerous macrophages. There was no evidence of malignancy. The patient began the CombiRx trial two months later. The patient tolerated the trial well over the next 12 months without progression of symptoms, until he presented with an acute episode of confusion and 
delusional behavior. Repeat brain MR revealed a diffusely enhancing mass involving both frontal lobes crossing the anterior corpus callosum (Figure 2). Stereotactic brain biopsy revealed a diffuse large B-cell lymphoma expressing CD20 and CD45. The MIB-1 index, reflecting mitotic activity, was $80 \%$ in the malignant cells. The patient underwent one cycle of methotrexate chemotherapy and expired one month following the diagnosis of primary central nervous system lymphoma.

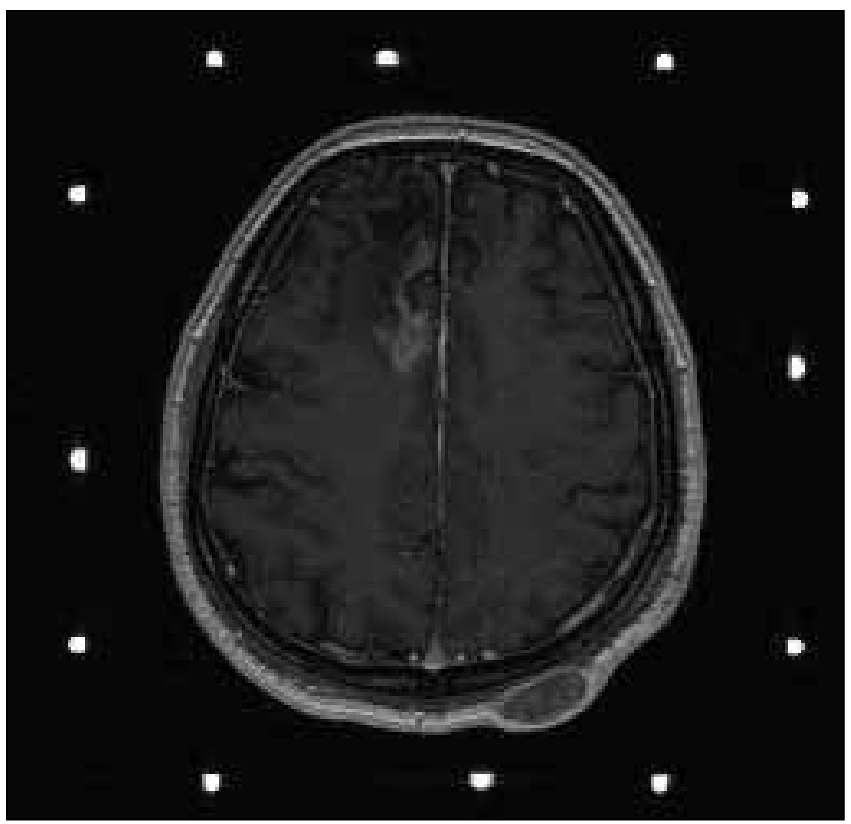

Figure 1: T-1 weighted axial brain MR demonstrating cystic encephalomalacia with heterogeneous gadolinium enhancement in the parasagittal right frontal lobe.

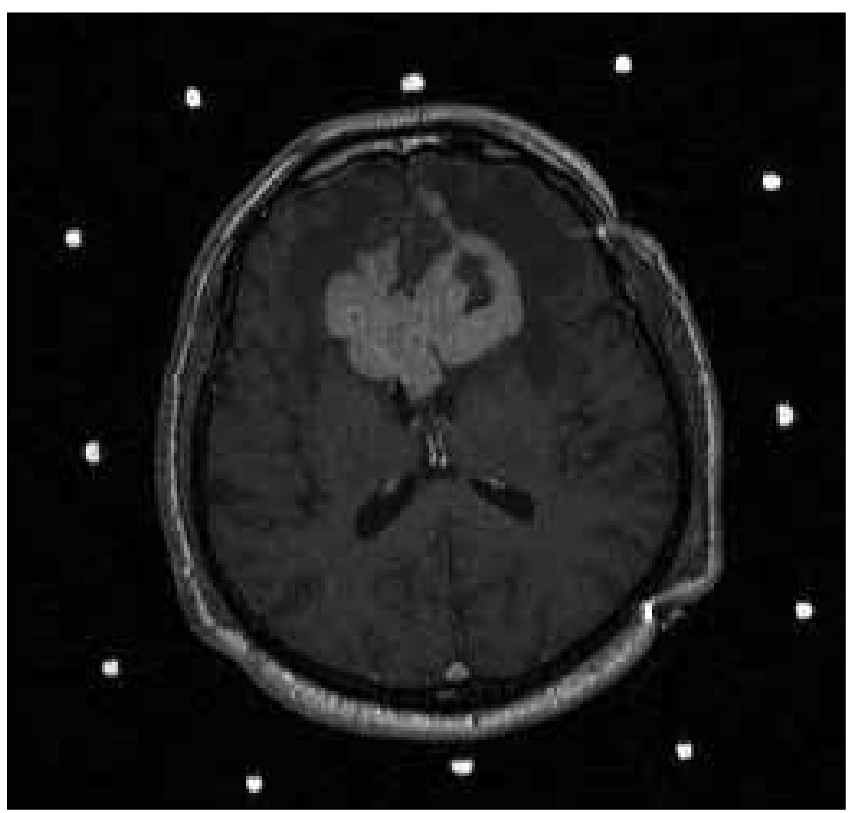

Figure 2: T-1 weighted axial brain MR demonstrating diffuse gadolinium enhancement of the frontal lobes involving the corpus callosum with vasogenic edema and mass effect.

\section{DISCUSSION}

Multiple sclerosis is chronic demyelinating disease affecting the central nervous system (CNS) and classically presents with exacerbating and relapsing neurological symptoms. Previous to the availability of immunosuppressive and immunomodulating (IS) treatments, reduced rates of cancer were linked to multiple sclerosis. During the past twenty years there has been a significant increase in the number of IS medications available for the treatment of MS $(3,5,6,8,17,18)$. Several reports over the past two decades have suggested an increase in cancer risk amongst MS patients, potentially related to the immunosuppressive therapies $(2,7,11-14)$. Other more recent reports have not found an increased risk of cancer in MS patients $(1,3,10)$. Recently, Lebrun and colleagues reported an exhaustive multicenter review of 7418 MS patients in France evaluating the impact of diseasemodifying therapies and the incidence of cancer (10). They found no evidence of an increased risk of cancer following the diagnosis of MS. In fact, they noted that men with MS had a statistically significant decrease in the incidence of cancer. However, there was an increased risk of breast cancer in women receiving more than one IS modality (10).

Primary central nervous system lymphoma (PCNSL) can be confused with multiple sclerosis $(4,15)$. Reportedly, $5 \%-10 \%$ of patients harboring a different disease are misdiagnosed with MS (15). There is no pathognomonic clinical feature, laboratory study or imaging feature for MS. Several conditions including Lyme disease, progressive multifocal leukoencephalopathy, mitochondrial disorders, metabolic deficiencies and lymphoma have been initially confused with MS $(4,15)$. While CNS lymphoma will often show diffuse enhancement with gadolinium administration and demyelinating plaques are much less likely to do so, this is not an absolute finding. In addition, corticosteroid administration will often result in substantial clinical improvement and potentially radiographic resolution of abnormal imaging findings in PCNSL, which can be interpreted as a steroid-induced remission of MS (4).

There is no reported link between the immunosuppressive therapy of interferon beta-1a and glatiramer acetate and the subsequent development of B-cell lymphoma. Interestingly, Krumbholz and co-workers reported their findings on B-cellactivating factor of the tumor necrosis factor (TNF) family (BAFF) (9). Human astrocytes were discovered to secrete BAFF following stimulation with interferon and TNF. They found that BAFF expression was strongly up-regulated to levels similar in lymphatic tissue in multiple sclerosis plaques in brain lesions with B-cell components (9). In addition, BAFF receptors were strongly expressed in PCNSL. They postulated that CNS-produced BAFF may support B-cell survival in inflammatory diseases, such as multiple sclerosis and primary B-cell lymphomas. Similar to our case, Yang and Wu reported a case of a 33-year-old patient with multiple sclerosis who developed central nervous system lymphoma three years following the initial diagnosis (16). Although their patient did receive beta interferon and subsequently developed an 
immunocompromised state, there is no compelling evidence of a causal relationship. They postulate that neoplastic transformation may occur in CNS inflammatory disorders such as MS (16).

\section{CONCLUSIONS}

The majority of the evidence currently suggests that patients with multiple sclerosis are not at an increased risk for the development of cancer, save possibly breast cancer in women. The differential diagnosis of multiple sclerosis is extensive. There is no conclusive evidence for an association between multiple sclerosis, immunosuppressive treatment and the development of PCNSL. However, continued dependence upon corticosteroid therapy is uncommon in RRMS and should alert the clinician to the possibility of PCNSL. Repeat gadolinium-enhanced imaging and cerebrospinal fluid analysis should aid in distinguishing between RRMS and PCNSL.

\section{REFERENCES}

1. Achiron A, Barak Y, Gail M, Mandel M, Pee D, Ayyagari R, Rotstein Z: Cancer incidence in multiple sclerosis patients and effects of immunomodulatory treatments. Breast Cancer Res and Treat 89: 265-270, 2005

2. Allen I, Millar J, Hutchinson M: General diseases in 120 necropsy-proven cases of multiple sclerosis. Neuropath Appl Neurobiol 4: 279-284, 1978

3. Confavreux C, Vukusic S: Non-specific immunosuppressants in the treatment of multiple sclerosis. Clin Neurol Neurosurg 106:263-269, 2004

4. DeAngelis LM: Primary central nervous system lymphoma imitates multiple sclerosis. J Neurooncol 9(2):177-181, 1990

5. Edan G, Miller D, Clanet M, Confavreux C, Lyon-Caen O, Lubetzki C, Brochet B, Berry I, Rolland Y, Fromet JC, Cabanis E, Iba-Zizen MT, Gandon JM, Lai HM, Moseley I, Sabouraud O: Therapeutic effect of mitoxantrone combined with methylprednisolone in multiple sclerosis: A randomized multicentre study of active disease using MRI and clinical Criteria. J Neurol Neurosurg Psychiatry 62:112-118, 1997

6. Ellison GW, Myers LW, Mickey MR, Graves MC, Tourtelotte WW, Syndulko K, Holevoet-Howson MI, Lerner CD, Frane MV, Pettler-Jennings P: A placebo-controlled, randomized, double-masked, variable dosage, clinical trial of azathioprine with or without methylprednisolone in MS. Neurology 39(8): 1018-1026, 1989
7. Fleming S, Blake RL Jr: Patterns of comorbidity in elderly patients with multiple sclerosis. J Clin Epidemiol 47: 1127-1132, 1994

8. Goodkin DE, Rudick RA, Vanderbrug-Medendorp S, Daughtry MM, Schwetz KM, Fisher J, Van Dyke C: Low dose oral methotrexate reduces the rate of progression in chronic progressive multiple sclerosis. Ann Neurol 37:30-40, 1995

9. Krumbholz $M$, Theil D, Derfuss $T$, Rosenwald A, Schrader F, Monoranu C-M, Kalled SL, Hess DM, Serafini B, Aloisi F, Wekerle $H$, Hohlfeld R, Meinl E: BAFF is produced by astrocytes and up-regulated in multiple sclerosis lesions and primary central nervous system lymphoma. J Exp Med 201:195-200, 2005

10. Lebrun $C$, Debouverie $M$, Vermersch $P$, Clavelou $P$, Rumbach L, de Seze J, Wiertlevski S, Defer G, Gout O, Berthier F, Danzon A: Cancer risk and impact of disease-modifying treatments in patients with multiple sclerosis. Multiple Sclerosis 14: 399-405, 2008

11. Moller H, Kneller RW, Boice JD, Olsen JH: Cancer incidence following hospitalization for multiple sclerosis in Denmark. Acta Neurol Scand 84: 214-220, 1991

12. Palo J, Duchesne J, Wilkstrom J: Malignant diseases among patients with multiple sclerosis. J Neurol 216: 217-222, 1977

13. Sadovnick A, Eisen K, Ebers G, Paty D: Cause of death in patients attending multiple sclerosis clinics. Neurology 41: 1193-1196, 1991

14. Taylor L, Hugues RA, Mc Pherson K: The risk of cancer from azathioprine as a treatment for multiple sclerosis. Eur J Neurol 11: 141, 2004

15. Trojano M, Paolicelli D: The differential diagnosis of multiple sclerosis: Classification and clinical features of relapsing and progressive neurological syndromes. Neurol Sci 22:S98-S102, 2001

16. Yang JH, Wu SL: Multiple sclerosis preceding CNS lymphoma: A case report. Acta Neurologica Taiwanica 16(2):92-97, 2007

17. Yudkin PL, Ellison GW, Ghezzi A, Goodkin DE, Hughes RA, McPherson K, Mertin J, Milanese C: Overview of azathioprine treatment in multiple sclerosis. Lancet 338:1051-1055, 1991

18. Zephir H, Deseze J, Duhamel A, Debouverie M, Hautecoeur P, Lebrun C, Malikova I, Pelletier J, Senechal O, Vermersch P: Treatment of progressive forms of MS by cyclophosphamide: A cohort study of 490 patients. J Neurol Sci 218: 73-77, 2004 